\title{
Grid Connected PV System Case Study: Jiza, Jordan
}

\author{
Yousif El-Tous ${ }^{1}$ \\ ${ }^{1}$ Department of Electrical Engineering, Faculity of engineering Technology, Al-Balqa' Applied University \\ Amman, Jordan \\ Correspondence: Department of Electrical Engineering, Faculity of engineering Technology, Al-Balqa' Applied \\ University Amman, Al Jubaiha 11941, PO box 734, Amman, Jordan. Tel: 962-7-7943-0087. E-mail: \\ yousifeltous@yahoo.com
}

\author{
Received: May 2, 2012 Accepted: May 24, $2012 \quad$ Online Published: May 28, 2012 \\ doi:10.5539/mas.v6n6p92 URL: http://dx.doi.org/10.5539/mas.v6n6p92
}

\begin{abstract}
Jordan is known to be rich in the solar resource with an annual average of 5 peak sun hours, on the other hand it lacks oil and gas resources, in this paper a grid connected PV power plant is designed and simulated using HOMER software, the power plant is sized to supply Al Jiza load, the simulation results showed that a high capital cost is needed and the cost of energy is $0.16 \$ / \mathrm{kWh}$ which is still high but with incentives and decrease of the PV panels price the system will reach a feasible cost.
\end{abstract}

Keywords: PV, solar energy, power plant, solar irradiation

\section{Introduction}

Jordan is a non-oil-producing country and imports $96 \%$ of the energy used. As a consequence, energy imports accounts for roughly $22 \%$ of the GDP. The population's growth rate is high; about $2.3 \%$ per year. This causes the demand on energy sources, mainly oil products to increase rapidly. Implementation of renewable energy resources such as solar energy, will lead to economical, social and environmental benefits Y. Anagreh et al. (2009). Jordan on the other hand is very rich in renewable resources especially in solar energy, which indicates the potential for installing grid connected Photovoltaic systems. Extensive research was made in this field, Anagreh et al. (2009) presented an investigation of the solar energy potential for seven sites in Jordan and concluded that Jordan has a great solar energy potential which motivates the utilization of stand-alone or grid-connected solar energy systems. Mondal et al. (2011) studied the potential and viability of grid connected of 1 MW using RET screen simulation software for 14 widespread locations in Bangladesh and showed the favorable condition for the development of the PV systems in Bangladesh. Li et al. (2001) presented a study of a grid-connected PV system in Hong Kong, and showed that the energy payback period was estimated to be 8.9 years.

Y. Udea et al. (2009) performed an analysis of various system configurations and orientations of grid-connected PV systems and showed the effect of the orientation and model of PV panels on the total energy yield. G. Mulder et al. (2010) presented a study of grid-connected PV systems for residential houses with energy storage, and studied the relation between storage size and energy flow to the grid in Belgium, while J. De La Hoz et al. (2010) performed an technical and economic analysis of grid-connected systems in Spain during the period 1998-2008, and intended to explain the evolution by focusing on the key growth factors and drivers embedded in the legal, economic and technical framework of the PV energy policy.

Sopian et al. (2009) studied the optimization of a stand-alone PV hybrid system for a household in Malaysia using HOMER simulation software, and showed that the least expensive system is composed of a $2 \mathrm{~kW}$ PV and $1 \mathrm{~kW}$ wind turbine. Numerous studies were conducted on the subject (Ruther \& Zilles, 2010; Aymope et al., 2011; Turkay \& Telli, 2011).

This paper presents an analysis for a grid-connected photovoltaic system for Al Jiza location in Amman, the capital of Jordan, and energy production costs and incomes are analyzed, the system configuration is simulated using the Hybrid Optimization Model for Electric Renewable (HOMER).

\section{Site Characteristics}

Al Jiza is located (25) km south of Amman the capital of Jordan, Figure 1 shows the location of Jiza in Jordan, it 
is located on latitude $31^{\circ} 42^{\prime} 14.68^{\prime \prime} \mathrm{N}$ and longitude $35^{\circ} 57^{\prime} 8.47^{\prime \prime} \mathrm{E}$, the temperature is warm in summer and moderate in winter, with temperature range of 24 to $33 \mathrm{C}$ in summer and as low as $0 \mathrm{C}$ in winter The area of $\mathrm{Al}$ Jiza is characterized by vast a plain area which is perfect for Photovoltaic power plants projects, Figure 2 shows the topographical map of Al Jiza. Figure 3 shows a vast plain surface with an area of (2.5) $\mathrm{km}^{2}$ which is perfect for the implementation of the PV power plant of our project, knowing that the area needed for our PV power plant is less than $(0.06) \mathrm{km}^{2}$.

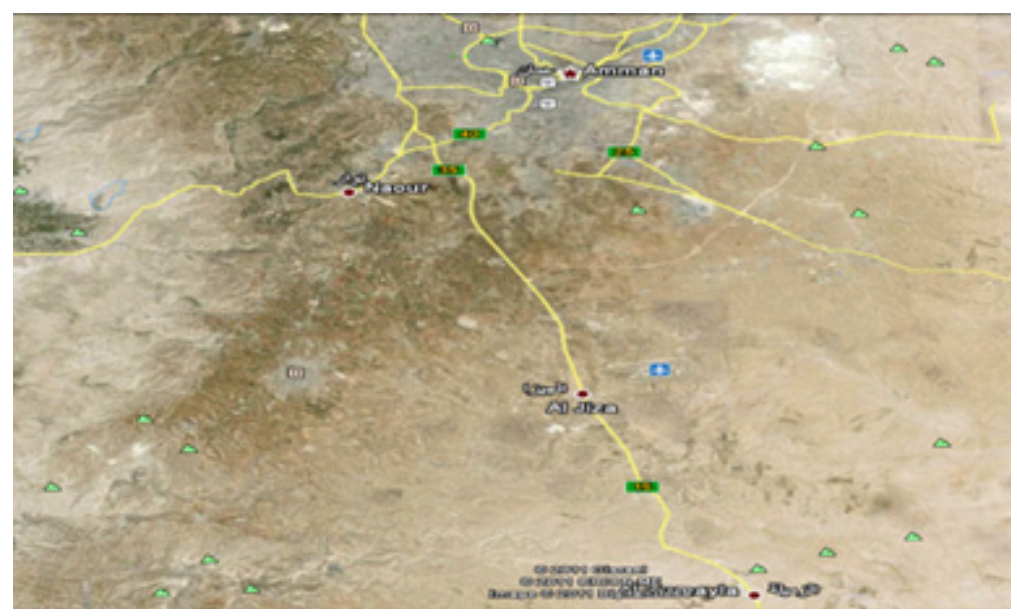

Figure 1. Jiza location in Jordan

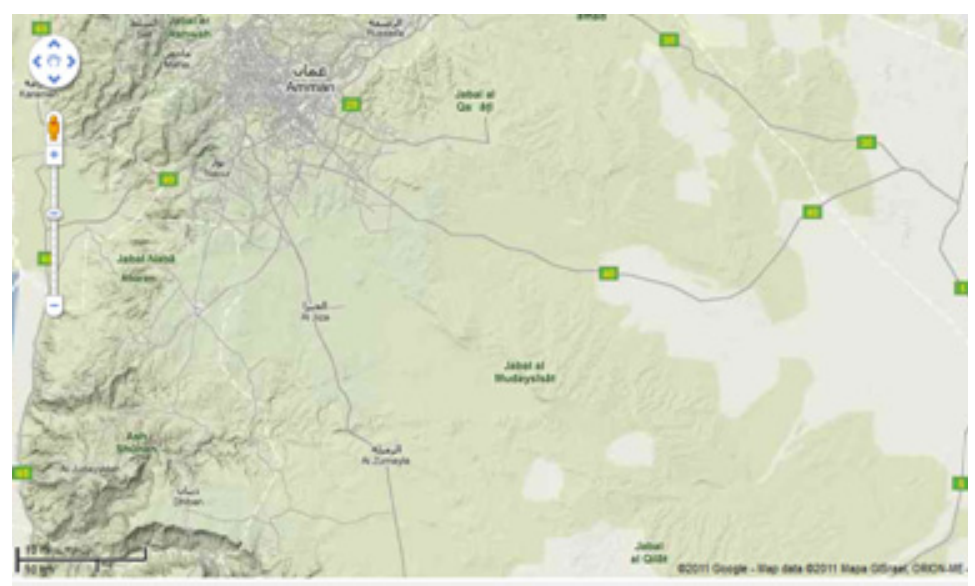

Figure 2. The topographical map of Al Jiza

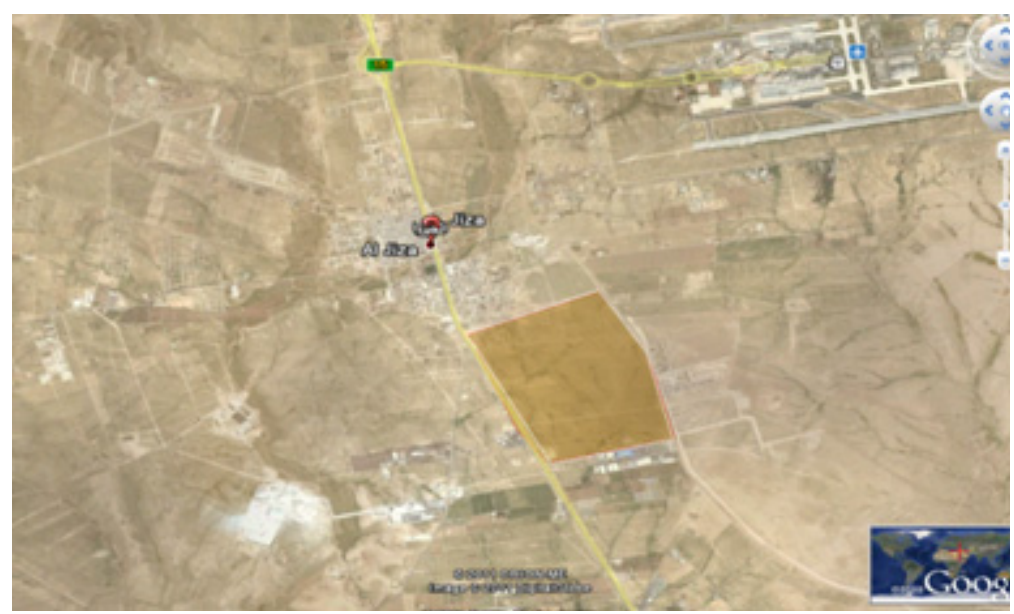

Figure 3. PV power plant location 


\subsection{Solar Irradiation}

The solar irradiance data were obtained from B.O.C. (2010), www. dos.gov.jo, SWERA (2011) and were analyzed using HOMER the average monthly solar irradiance data for Jiza location is shown in Table 1. It can be seen from Table 1 that the average solar radiation in Jiza is very high $\left(5.753 \mathrm{kWh} / \mathrm{m}^{2} / \mathrm{d}\right)$, which is suitable for Photovoltaic generation, and the clearness index shows that Jiza is a sunny area, which predicts a promising energy production. It is shown in Figure 4 that the maximum solar radiation occurs in July with the irradiation of $8.33 \mathrm{kWh} / \mathrm{m}^{2} / \mathrm{d}$ which is a very high value, from April to September the solar radiation exceeds $6 \mathrm{kWh} / \mathrm{m}^{2} / \mathrm{d}$, and the lowest average radiation is in the month of December with $3.1 \mathrm{kWh} / \mathrm{m}^{2} / \mathrm{d}$. It's clear from the site analysis and solar radiation data that Jiza location has a great potential for a PV energy generation project.

Table 1. Solar radiation and clearness index for Jiza

\begin{tabular}{|c|c|c|}
\hline Month & Clearance index & $\begin{array}{c}\text { Average daily radiation } \\
\left(\mathrm{kWh} / \mathrm{m}^{2} / \mathrm{d}\right)\end{array}$ \\
\hline January & 0.60000 & 3.3807 \\
\hline February & 0.61000 & 4.2096 \\
\hline March & 0.61800 & 5.3045 \\
\hline April & 0.64000 & 6.4882 \\
\hline May & 0.66053 & 7.3400 \\
\hline June & 0.68987 & 7.9100 \\
\hline July & 0.74000 & 8.3319 \\
\hline August & 0.71000 & 7.4288 \\
\hline September & 0.70740 & 6.4300 \\
\hline October & 0.70000 & 5.1669 \\
\hline November & 0.64400 & 3.8031 \\
\hline December & 0.60000 & 3.1404 \\
\hline Annual average & 0.6690 & 5.753 \\
\hline
\end{tabular}

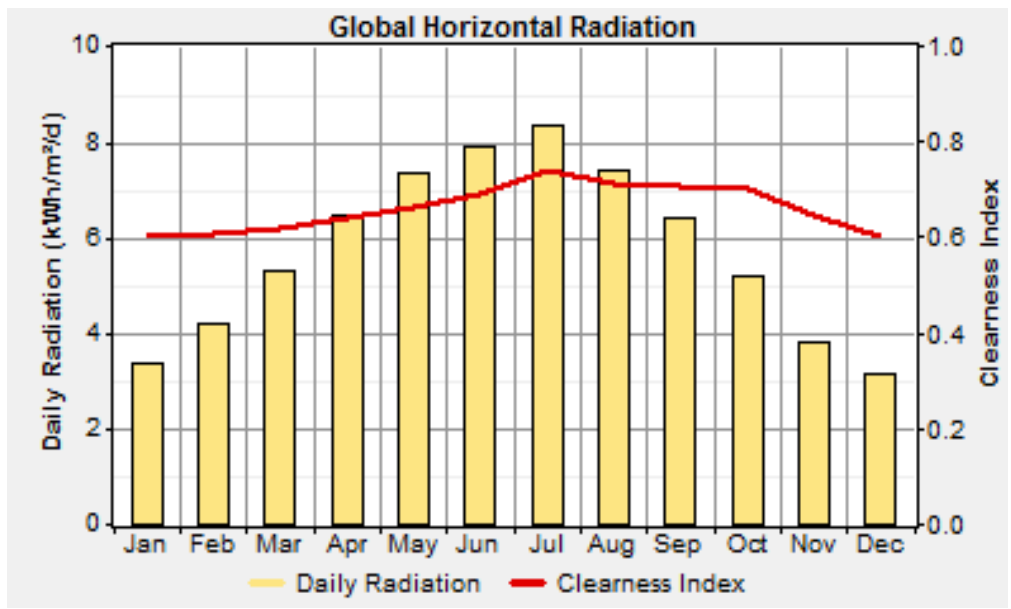

Figure 4. Solar radiation and clearness index for Jiza

\section{The Load Profile}

Load profile data for Jiza were obtained from www. eosweb.larc.nasa.gov, and Lambert (2005). That data were given in two parts as shown in Figures 5, 6 the week day load profile and the weekend load profile. Jiza load is divided into two main parts the higher consuming part is of residential consumer's loads, the second part is an approximately constant load which represents Al Malika Alia'a Airport. Form Figures 5, 6 we can see that the load profile varies form weekday and weekend and it is slightly higher in the weekend days and that's due to the nature of the characterized with residential consumer for the major part. Figure 7 shows the average monthly load for Jiza. The main characteristics of the Jiza load are shown in Table 2, which are: the average load (kWh/d), 
the average load power $(\mathrm{kW})$, the Peak load $(\mathrm{kW})$ and the Load factor.

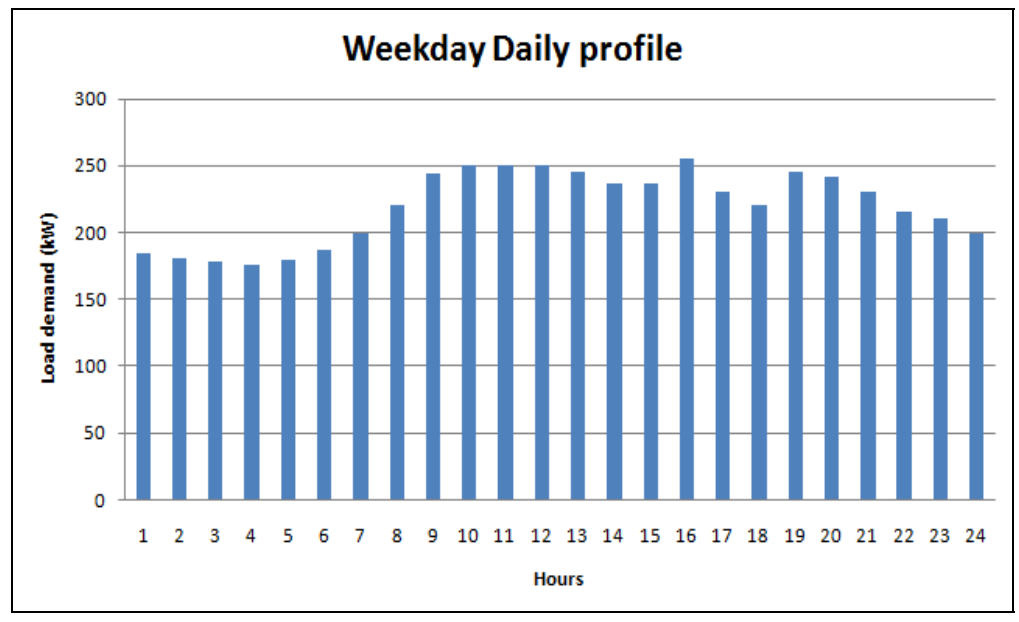

Figure 5. Weekday Daily load for Jiza

Table 2. Jiza Load parameters

\begin{tabular}{cc}
\hline Parameter & Value \\
\hline Average load $(\mathrm{kWh} / \mathrm{d})$ & 5,045 \\
Average load $(\mathrm{kW})$ & 210 \\
Peak load $(\mathrm{kW})$ & 451 \\
Load Factor & 0.466 \\
\hline
\end{tabular}

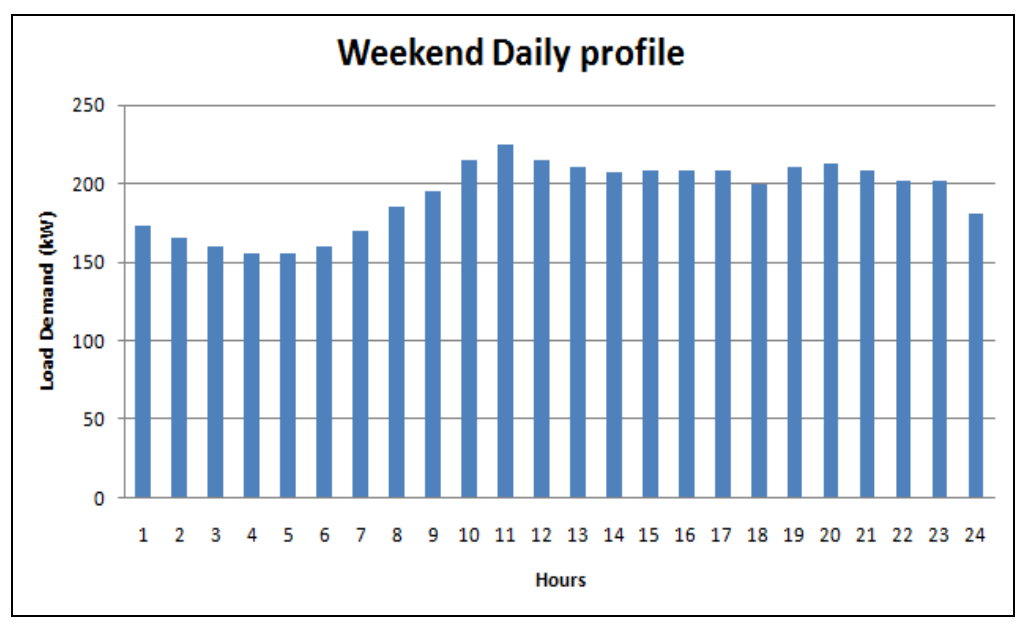

Figure 6. Weekend daily load for Jiza 


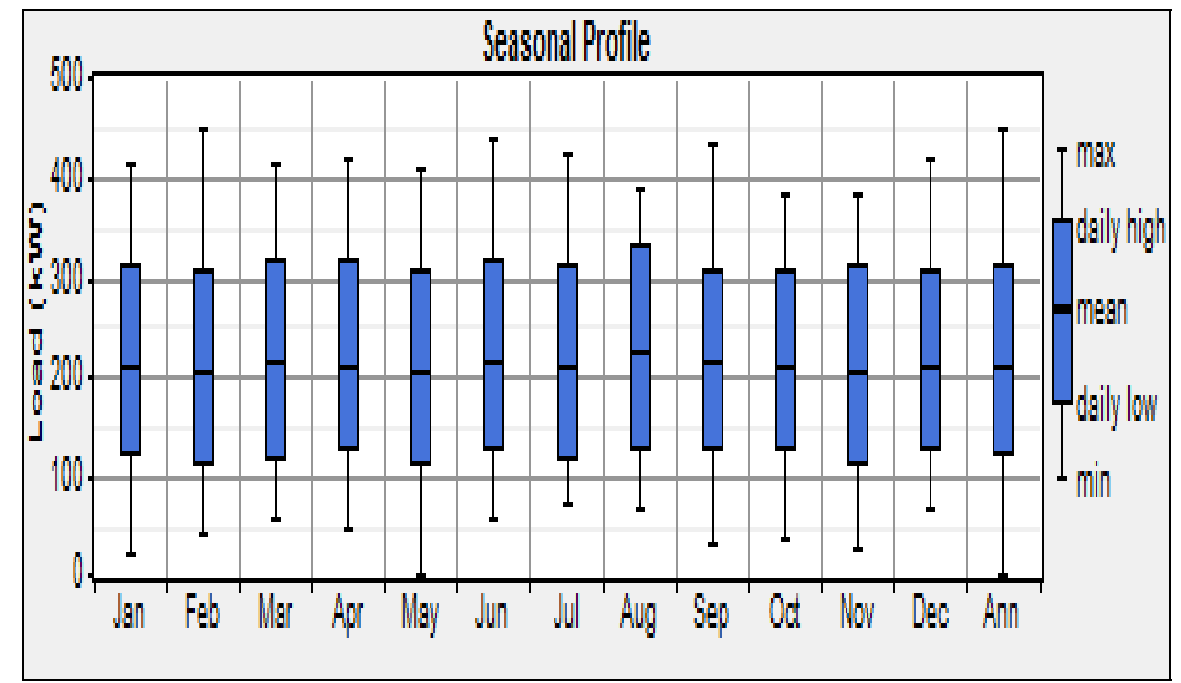

Figure 7. Monthly average load for Jiza

\section{System Configuration}

The grid connected system was modeled using HOMER program www. sunelec.com, 2011. Figure 8 shows the system configuration used in this paper. The system is composed of $1000 \mathrm{~kW}$ of PV and $1000 \mathrm{~kW}$ converter with the load of an average consumption of $5 \mathrm{MWh} / \mathrm{d}$ and peak demand of $451 \mathrm{~kW}$, Table 3 summarizes the components sizes and cost used in the system simulation. The cost of electrical energy purchase rate from the grid is set to 0.10 US\$ while the sellback price is 0.05 US\$ with Net metering, an additional 20000 \$ yearly Maintenance and operation for the project.

Table 3. Components sizes and cost used in the system simulation

\begin{tabular}{ccccc}
\hline Component & Size (kW) & $\begin{array}{c}\text { Capital Cost } \\
{[\mathbf{1 7 ]}(\mathbf{\$} / \mathbf{k W})}\end{array}$ & $\begin{array}{c}\text { Maintenance and } \\
\text { operation(\$/year) }\end{array}$ & $\begin{array}{c}\text { Total capital } \\
\text { cost(\$) }\end{array}$ \\
\hline PV panels & 1000 & 3000 & 0 & 3000000 \\
Inverter & 1000 & 300 & 8000 & 300000 \\
\hline
\end{tabular}

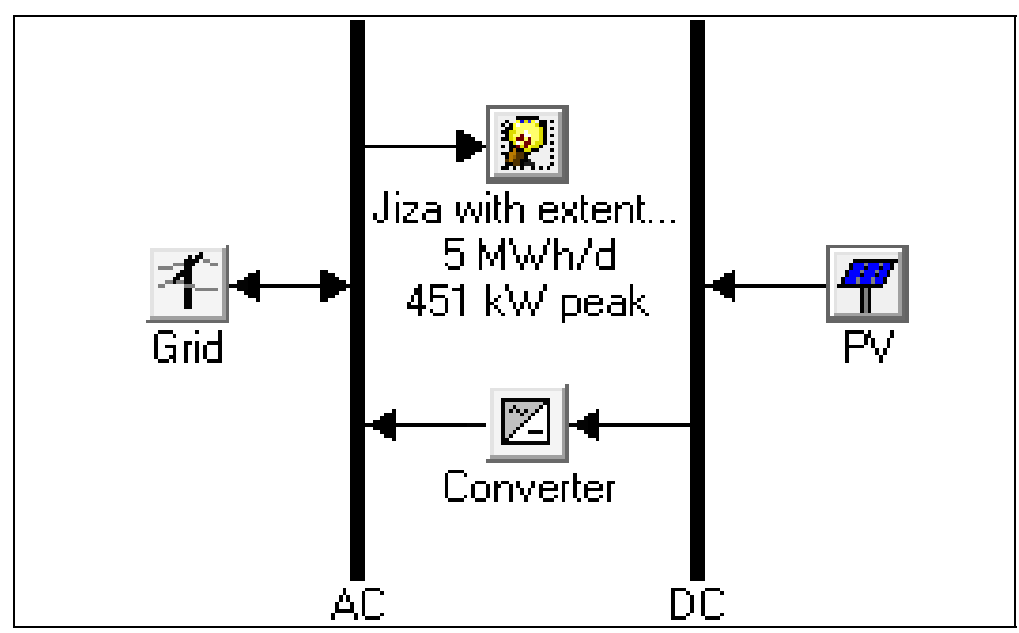

Figure 8 . The grid connected PV system configuration 


\section{Results and Discussion}

After running the data through HOMER the optimal results data for the system in Amman is shown in Table 4, the 64 percent of the load fraction is supplied by the PV system and the other 36 percent is supplied from the grid, the 32 percent of the load is sold back to the grid and that happens when the PV supply is greater than the demand and that occurs in the midday period when the sun is high in the sky. Figure 9 shows the monthly electric production by the PV system and by the grid, the chart shows that the PV production increases in summer months namely (July, August, September), and least in the winter months.

Table 5 shows the costs associated with the system, the highest part of the system is due to the PV panels but has no or low maintenance and operation costs on the other hand the converters and grid connection has a relatively low capital cost but it contribute to the total cost by the maintenance and operation cost.

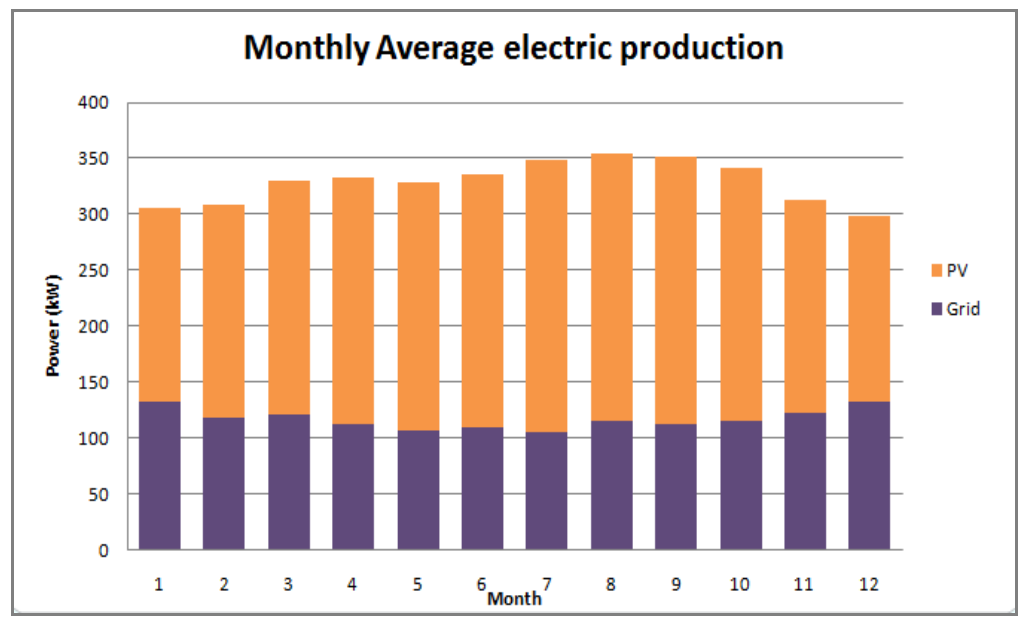

Figure 9. Monthly electric production

Table 4. Electrical simulation data

\begin{tabular}{ccc}
\hline Component & $\begin{array}{c}\text { Production } \\
(\mathrm{kWh} / \mathrm{yr})\end{array}$ & $\begin{array}{c}\text { Fraction } \\
\%\end{array}$ \\
\hline PV array & $1,856,165$ & 64 \\
Grid purchases & $1,024,824$ & 36 \\
Total & $2,880,989$ & 100 \\
Load & Consumption & Fraction \\
AC primary load & $1,841,423$ & 68 \\
Grid sales & 853,949 & 32 \\
Total & $2,695,371$ & 100 \\
Converter & Losses & Fraction \\
Inverter & 185,615 & 0.01 \\
\hline & System & \\
\hline Excess electricity & Unmet electric load & Capacity shortage \\
0 & $\%$ & 0.00 \\
\hline
\end{tabular}


Table 5. Costs associated with the system

\begin{tabular}{cccc}
\hline Component & Capital cost $\mathbf{( \$ )}$ & O\&M(\$) & Total $\mathbf{( \$ )}$ \\
\hline PV & $3,000,000$ & 0 & $3,000,000$ \\
Grid & 0 & 224,947 & 224,947 \\
Converter & 300,000 & 102,267 & 402,267 \\
Other & 0 & 255,667 & 255,667 \\
System & $3,300,000$ & 582,881 & $3,882,880$ \\
\hline
\end{tabular}

\section{Conclusion}

Jordan is very rich in the solar resources and has a great potential for PV powered projects, in this paper a proposed PV power plant is planned to meet the load of Al Jiza near Amman, the system is sized and simulated using HOMER, and the resulted system is composed of $1000 \mathrm{~kW}$ of PV and $1000 \mathrm{~kW}$ converter with the load of an average consumption of $5 \mathrm{MWh} / \mathrm{d}$ and peak demand of $451 \mathrm{~kW}$, the total capital cost is high which is typical for PV system, and the cost of energy is $0.16 \$$ which is still a high cost, the system is still unfeasible without the incentives but prices trends are decreasing.

\section{References}

Anagreh, Y., Bataineh, A., \& Al-Odat, M. (2009). Solar energy potential in Jordan. ICEGES.

Aymope, L., Duffy, A., McCormack, S., \& Conlon, M. (2011). Measured performance of a $1.72 \mathrm{~kW}$ rooftop grid connected photovoltaic system in Ireland. Energy conversion and management, 52, 816-825. http://dx.doi.org/10.1016/j.enconman.2010.08.007

Business Optimization Consultants B.O.C. (2010). Jordan - Touristic Sites - Amman". Kinghussein.gov.jo. Retrieved -07-04.

De La Hoz, J., Boix, O., Martin, H., Martin, B., \& Gralles, M. (2010). Promotion of grid-connected Photovoltaic systems in Spain: performance analysis of the period 1998-2008. Renewable and sustainable energy reviews, 14, 2547-2563. http://dx.doi.org/10.1016/j.rser.2010.07.059

Lambert, T., Gilman, P., \& Lilienthal, P. (2005). Micropower system modeling with HOMER, Integration of Alternative Sources of Energy, Farret FA, Simões MG. John Wiley \& Sons.

Li, D., Cheung, K. L., Lam, T., \& Chan, W. (2011). A study of grid-connected photovoltaic PV system in Hong Kong. Applied Energy.

Mondal, Md., \& Islam, A. (2011). Potential and viability of grid connected solar PV system in Bangladesh. Renewable energy, 36, 1869-1874. http://dx.doi.org/10.1016/j.renene.2010.11.033

Mulder, G., De Ridder, F., \& Six, D. (2010). Electricity storage for grid-connected household dwellings with PV panels. Solar energy, 84, 1284-1293. http://dx.doi.org/10.1016/j.solener.2010.04.005

Nasa surface meteorology and solar energy. (2012). http://eosweb.larc.nasa.gov

Ruther, R., \& Zilles, R. (2010). Making the case for grid-connected Photovoltaic in Brazil. Energy policy, 39, 1027-1030. http://dx.doi.org/10.1016/j.enpol.2010.12.021

Solar and Wind Energy Resource Assessment (SWERA). (2011). http://swera.unep.net 8/3/201

Solar system equipment prices, Sun electronics. (2012). http://www. sunelec.com

Sopian, K., Fudholi, A., Ruslan, M., Sulaiman, M., Alghoul, M., ... Zaharim, A. (2009). Optimization of a stand alone wind/PV hybrid system to provide electricity for a household in Malaysia. IASME/WSEAS international conference on energy \& environment.

The Hashemite kingdom of Jordan department of statistic (DOS). (2012). Retrieved from http://www.dos.gov.jo home /dos e/main/index.htm

Turkay, B., \& Telli, A. (2011). Economic analysis of standalone and grid connected hybrid energy systems. Renewable energy, 36, 1931-1943. http://dx.doi.org/10.1016/j.renene.2010.12.007

Udea, Y., Kurokawa, K., Kitamura, K., Yokota, M., Akanuma, K., \& Sugihara, H. (2009). Performance analysis of various system configurations on grid-connected residential PV systems. Solar energy materials \& solar cells, 945-949. http://dx.doi.org/10.1016/j.solmat.2008.11.021 